DOI: 10.1515/ausp-2015-0035

\title{
Homeward Journey through Poetry: Wallace Stevens's The Poem that Took the Place of a Mountain
}

\author{
Boróka PROHÁSZKA-RÁD \\ Sapientia Hungarian University of Transylvania (Miercurea Ciuc, Romania) \\ Department of Humanities \\ boroprohaszka@yahoo.com
}

\begin{abstract}
Analyzing Stevens's 1952 The Poem that Took the Place of a Mountain I trace the laborious journey the persona of the poem undertakes - an external as well as an internal adventure - transforming thus the world into a possible home. I show how the poem - through its self-reflexive nature and complex system of interwoven external and internal images and circular movements - may offer the persona a sense of self and home in space and time among the fragments of the broken universe.
\end{abstract}

Keywords: Stevens, poetry, metatext, transcendental

A central preoccupation of Stevens's poetry consists in questioning what connects the image about the world created by the self with reality and what road the creative imagination travels in order to make sense of a universe that lacks a central ordering idea. The Poem that Took the Place of a Mountain attempts to answer these questions taking its reader on a journey of self-discovery, even if the answers Stevens formulates are always conditional and undermined, deconstructed by the subtle irony of his works.

The title already foreshadows the fundamental themes of this 1952 short poem: the abstract, the created poem takes the place of a concrete, un-created mountain, a movement from the objective to the subjective, toward a new interpretation of reality. Considering the symbolic potential of the word mountain, we may already state that the poem will present a view of the world different from the everyday, ordinary one. It will be a view from above, from the top of a mountain - in all cultures mountains being holy places where one gets closer to and may connect with God, with the transcendental. Stevens also pre-signals the self-reflexive nature of his work using the word "poem" in the title - as he often does. 
In this literary universe a work of art - the poem - takes the place of a mountain. The fixed physical object, the natural is replaced by something of man's own creation. As stated, Stevens's primary concern was the relation between the mind, art and reality in an era when the belief in God had vanished and in which people felt lost without the values and comfort once given by faith and the thought of heaven. Thus, the task of poetry is to offer a believable new "grand narrative" in a decreative age. If God is dead - as Nietzsche argues -, the mountain where one would go to get closer to him and to heaven, has lost its functionality, it has been stripped of its purpose and value. This function and purpose - according to Stevens - can only be taken over by poetry. The mountain where one met the transcendental in the time of the religious world view is replaced by a creation of the human mind and imagination, a constructed spiritual object. The title also suggests the shift so typical of Stevens's poems: from the exterior objective description to the subjective (Palmer 1992,1), a metamorphosis that according to the title has already taken place.

There it was, word for word,

The poem that took the place of a mountain.

Reading the title one might expect to find in what follows the poem it mentions. The distancing "There it was", however, reveals that this is a poem about the poem of the title. Meta- and intertextuality is thus strengthened, the reader's expectations are undermined and turned toward another direction. But as this presentation also happens through a work of art, we witness a doubling of the theme, with the actual poem fulfilling all the functions and purpose ascribed to its topic.

"[...] word for word" - states Stevens in this very first line, again an element of intense self-reflexivity. Every single word is necessary in order to make up a creation that is whole and capable of playing the role ascribed to it in the title. The past tense verbs of the stanza (was, took) reinforce distancing: the poem we are told about has already been written, the shift from the mountain to the poem, from the objective/exterior to the subjective/interior dimension has already taken place. At the same time, the inter- and metatextual character of these lines suggests that this kind of shifting is a continuous process, that the poem we are reading is going to re-enact the one it is talking about. "There it was", but not fixed and eternal, for it is made up of words - just like the one we are reading open to multiple interpretations, reinterpretations and doomed to be replaced.

He breathed its oxygen,

Even when the book lay turned in the dust of his table.

In this second stanza the persona of the poem appears with the - again distancing - third person singular pronoun "he". Alan Filreis suggests that Stevens 
is known "for a series of quintessentially modernist poems-about-poetry in which a spectral second- or third-person pronoun behaves like a depersonalized, meditative figure" $(1994,2)$. Here the persona "he" may be interpreted as the alter ego of the poet, the alter ego of any reader of poetry, or a universal representation of the individual of the mid-twentieth century. First we are offered an objective exterior image of this persona - obviously a scholar surrounded by, "living in" his books, breathing the oxygen of poetry even when not actually reading. The book turned upside down emphasises this scholarly character: it is not put away on a shelf, but left on the table, at hand all the time. ${ }^{1}$

Also within this stanza the topic poem is enlarged: it is not merely an object replacing the mountain, but a whole universe in itself, its oxygen is what the persona breathes. The term "oxygen" - used instead of the customary air - refers back to the mountain mentioned in the title that we associate with fresh and clean air, while the noun "dust" describing the actual setting already indicates the difference in value of the real and the imagined spaces. ${ }^{2}$

It reminded him of how he had needed

A place to go to in his own direction.

At this point the topic poem becomes a reminder of past wishes and desires. And, from this point on, the poem which started with an exterior, objective description of the persona's world, turns inward again - a journey starts not only into the workings of art/poetry but also into the persona's/recipient's internal world, to a presentation of human needs and dispositions. The use of the past perfect in stating these desires and the opening statement "It reminded him" suggest that such needs and dispositions are now a matter of the past. Neither do the following stanzas settle the questions whether they have ever been fulfilled. Still, the fact that their presentation takes up more than half of the poem indicates their importance: even if they were forgotten, they did not vanish forever, the struggle for their fulfilment was just temporarily suspended. At the same time, the title may also be suggesting an answer: if the poem took the place of the

1 Another interpretative path opens up with the word "book" which may refer to the Bible, reinforcing the symbolic valences of the "mountain" as a reference to Biblical figures climbing holy mountains in order to communicate with the transcendental.

2 The term "dust" may once again indicate a possible Biblical reading of the poem, where the upper sphere, the mountain, respectively the poem are associated with "oxygen", while the secular, human world is that of dust, a reference to the Biblical "Then the Lord God formed the man of dust from the ground and breathed into his nostrils the breath of life, and the man became a living creature" (Genesis 2:7), as well as "for you are dust and to dust you shall return" (Genesis 3:19), "All came from the dust and all return to the dust" (Ecclesiastes 3:20); or "And wherever they do not receive you, when you leave that town shake off the dust from your feet as a testimony against them" (Luke 9:5) similarly to "And if anyone will not receive you or listen to your words, shake off the dust from your feet when you leave that house or town" (Matthew 10:14). 
mountain, it became the fulfilment. Beside this it also took up a second role: that of reminding, bringing back the memory of such past longing, blunted by time.

This longing becomes the element individualising the persona: "to go to in his own direction". This need is the universal human desire to find one's own path - calling to mind Robert Frost's The Road Not Taken. It also highlights the fact that not a place, a setting is personal, unique and individualising, not one's destination is the defining element of one's self, but much rather the individual direction, the journey one takes.

How he had recomposed the pines,

Shifted the rocks and picked his way among clouds,

Following the persona on this internal voyage we find elements of a physical climb up a mountain representing here inner happenings, the spiritual journey of the self from the dusty table of his external reality to the clean, fresh oxygen of the mountain, to the imaginary world created through and in art, and implicitly to the height of consciousness and self-understanding. On this journey elements of nature, the pines are deconstructed and "recomposed", suggesting that travelling one's inner world will lead to the dismantling of one's pre-existing concepts about reality. Still, such a deconstruction does not lead to nothingness or nihilism, but to a reinterpretation of the world.

Rocks are shifted. The rock in Stevens's poetry holds a special significance: it is the symbol of the empirical, physical world, the real thing, the base. The real is only the base, but it is the base - argues Stevens again and again in his works, suggesting that any creative process is founded on some bit of the empirical world which the imagination deconstructs and reconstructs into a new order, a new understanding of both the surrounding and our internal universes.

The second half of the line, "and picked his way among clouds", suggests an upward movement. The persona - having found or chosen his "direction" - is moving upward among diminished visibility conditions. A telling image is created of the self's internal journey, which seems reversed though. We would expect the persona to "descend" toward the depths of his soul, to his subconscious. But Stevens emphatically chooses to display this as an upward movement, stressing the effort that is needed in order to attain a clear view of the self. The imagery representing this inner quest continues the juxtaposition of the external and the internal. The world within and the one surrounding us are confusing and chaotic, cloudy. And one can only find his path and place under such circumstances if one follows his own path and confronts this confusion on his own terms - "for the outlook that would be right." This desired appropriate outlook should replace the dusty world around the table as well as the confusion among the clouds through which the laborious journey takes our traveller. Such a 
path might ultimately lead one to the right perspective of both the external reality and one's inner world. From such an outlook the self, fractured and incomplete in the lower world of dust and clouds, seems complete and whole:

For the outlook that would be right,

Where he would be complete in an unexplained completion:

The qualifier attached to this "completion" is "unexplained." In a world stripped of transcendence, where all the gods are dead, nothing can be complete, least of all the human self. There is no more use in climbing the mountain like Moses did to listen to the words and hear the message of God. But the struggle, the journey itself, not the place but the way one gets there, may evoke the necessary disposition of the self to see the world and one's place in it clearly. The poem - in an "unexplained" way - becomes capable of conferring wholeness and transcendence in a fragmented and broken world, where meaning is blurred by clouds, and rocks shift taking on new forms and new meanings with every step.

The exact rock where his inexactnesses

Would discover, at last, the view toward which they had edged,

Where he could lie and, gazing down at the sea,

Recognize his unique and solitary home.

The shifting rock of the earlier stanza here turns into the "exact rock", one physical, empirical, fixed and well-defined bit of reality, clear, solid and eternal, which ties the self to the surrounding reality. This "exact rock" becomes the base from which a new perspective, a new understanding of the world may start out. As Stevens states in a letter: "[...] the whole effort of modern art has been about this: the attachment to real things" (qtd. in Filreis 1992, 10).

The "inexactnesses" of the self - starting out from the reality of the rock discover a view of the world and of the self that he has longed for, a stable position from where intense observation and intensive experience are possible. The twofold movement - the pseudo-external movement upwards and the internal movement towards the depths of the ego - come to a momentary standstill from where the view upon both the surroundings and the internal universe - even if in a continuous process of change - is clear and meaningful, conveying a whole picture. The self has always longed for this momentum, where all the rocks of the physical, real world and all the inexactnesses, all the spiritual fragments would come together to create wholeness. This is the momentum and the place where the ego and the world surrounding it would be rearranged - not into a random arrangement of broken bits, but into order and meaning. This is the ultimate human desire: to come together, be one and create a whole with the world. 
The persona of the poem halts at this point, comes to a total rest with the verb "lie." The self has reached a position from where he can observe, may gaze down at the world and himself. Gazing at the world means intensely and continuously observing it with surprise and admiration, discovering it anew - just like Nietzsche's child. ${ }^{3}$ This gazing involves the intense activity of the senses, of the intellect, but it also evokes emotions and the creative activity of the imagination. As Walzer argues, in Stevens' poetry "[r]eality [...] might exist in the process of trying to refer to it, meditate on it, - in short, trying to perceive it" $(2000,50)$.

The object of this gaze is yet another element of manifold symbolic valences: the sea. This symbol of endlessness, of eternity and of continuous change, uninhabited and eternally renewing itself, suggests here that when facing the great ontological and epistemological questions of existence man is alone. From ancient times the sea has also been the terrain of quests for truth and for knowledge, where man was tested and confronted with the world and his own limitations. Its ever-changing nature also illustrates Stevens's ideas concerning reality, for as Walzer states - there is "an uncertainty about what a picture of plain reality might look like. [...] Stevens is hesitant to settle on too fixed or certain a notion of what reality is" $(2000,47)$. A similar argument comes from Pfau: "Stevens invites us to surrender the individual authority of knowing clearly to become 'part and particle' of the universe, as we come to reconceive our notions of what is real or true in a never-resting movement of figuration" $(1999,608)$.

This image of the sea may call to mind Husserl's phenomenology or Heidegger's hermeneutic phenomenology. But Stevens was not a phenomenologist and nor a nihilist. As Leonard and Wharton (1988) suggest, Stevens's poetry reveals another type of thinking according to which the world is what you make of it. The objective, empirical elements of the world are the material from which the imagination creates a new worldview. Reality is a process, and all one can do to understand it is to find a solid position and observe the ever-changing images produced by the metamorphoses of the world.

A further element of this presentation of the self's quest for knowledge and understanding of the world is the fact that the persona of the poem does not gaze up to the sky - despite being positioned on the symbolic top of the mountain. The poem explicitly states: "gazing down at the sea". For the sky is empty, there

3 According to Stevens, the artist deconstructs existing concepts and, starting out from these disassembled elements of the real, the creative imagination creates what he calls the "fluent mundo", the "supreme fiction", a poetic order of things. Nietzsche also presents a similar process in his camel - lion - child threefold metamorphosis, where the camel represents the phase of acceptance of the given, the lions is the No, the revolt against the given and its deconstruction, while the child is the Yes, the creation of a new perception of the world (Thus Spoke Zarathustra). The same concept appears in Cassirer's poetics who argues: "Like all the other symbolic forms art is not the mere reproduction of the ready-made given reality. It is one of the ways leading to an objective view of things and of human life. It is not an imitation but a discovery of reality" (An Essay on Man). 
is no point searching for heaven, for God, for meaning and wholeness in the sky. Therefore, one should look for meaning in the world of reality, the one man was "thrown into" - to use Heideggerian terminology - and also down into the depths of one's soul. And although the sea, nature is not capable of offering transcendence and does not carry any meaning or value beyond itself, it functions as the base, where the persona recognizes "his unique and solitary home." Here again the idea of a world stripped of transcendence is present: the home is unique and solitary, there is no transcendental power to guide one toward some heavenly adobe. Finding one's self and direction in the world is not a communal and collective quest, but an individual and lonesome one. The self of the twentieth century lives in a universe of relativity where there are no absolutes (Walzer $2000,52)$. Still, through the intense observation of this reality and the changes it undergoes the creative imagination rearranges its elements into the "supreme fiction", a construct that is ephemeral but which may suspend disbelief and may satisfy the questing mind. As Stevens argues: "God is a symbol for something that can as well take other forms, as for example, the form of high poetry," and "After one has abandoned a belief in god, poetry is that essence which takes its places as life's redemption" (Adagia).

During the presented journey the persona goes through a transformation that correlates with Nietzsche's three metamorphoses: 1. after the longing and ardent needs of the past he accepts a fragmented world without meaning, 2. just to be reminded of the past longing by the poem and revolt against his circumstances (dust, clouds), to de-construct his pre-existent concepts (recomposing the pines, shifting the rocks), 3. to reach finally - through and within the poem - a new image of the world that feels like home, where one is complete. This new image is thus not pre-existent - as it would be according to Emerson ${ }^{4}$ - but it is created in the process of perception and the workings of imagination. Reality, truth in Stevens' view are "constructed domains" (Filreis 1992, 8). Stevens - though trained in the art of poetry by the confusing times of the first half of the twentieth century - did not question the value of literature, but he continuously felt "the need to decide exactly wherein the worth and efficacy of a literary work reside" (Burke qtd. in Filreis 1994, 7). He pondered much on the nature of writing and the function of poetry - a clearly modernist feature of his work. In A Primitive like an Orb he states:

We do not prove the existence of the poem.

It is something seen and known in lesser poems.

It is the huge, high harmony that sounds

A little and a little, suddenly,

By means of a separate sense.

4 According to Emerson, the poet's role is to excavate the pre-existing truth (The Poet). 
In this sense, his work fits well with that of T. S. Eliot as does some of his aesthetic rationale. In Adagia he argues: "Poetry is not personal", calling to mind Eliot's Tradition and Individual Talent. He also states: "Poetry must be irrational. The purpose of poetry is to make life complete in itself", as well as "In the absence of a belief in God, the mind turns to its own creations and examines them not alone from the aesthetic point of view, but from what they reveal, from what they validate and invalidate" (Adagia). Poetry for Stevens sometimes seems to be a therapeutic refuge from the chaotic and confusing mid-twentieth century:

\section{[...] Poetry \\ Exceeding music must take the place \\ Of empty heaven and its hymns.}

But while Eliot mourns the loss of religious tradition, Stevens celebrates the liberation of the mind from old myths. In his opinion, man needs to free himself from the ghosts of the past and achieve transcendence through art, the "supreme fiction". Poetry for him constitutes the one authentic defence of imagination facing the overwhelming external and internal confusion, for his own disposition was - states James Longenback - one of being at peace with the world: "Stevens often wrote a verse of high imagination but he was able to do so by understanding his place in the world of politics and economics" $(1991,8)$.

Stevens believed in the Romantic idea of the restoring power of poetry. The Poem that Took the Place of a Mountain through its self-reflexivity and complex system of interwoven external and internal images and circular movements from the objective to the subjective and back again is an excellent example of his literary credo: although poetry is something created by the human mind, if there is a fundamental need for belief, then man willingly turns towards poetry with the knowledge of this being his own creation and thus temporal and ephemeral, he accepts momentarily that it is the truth, real and eternal, and so through poetry an understanding and realization of what is achieved (Leonard and Wharton 1988, 71). Up the imaginary mountain, among the fragments of the shattered universe the self undertakes his homeward journey. 


\section{Works cited}

Cassirer, Ernst. An Essay on Man: An Introduction to a Philosophy of Human Culture. http://www.monoskop.org/images/1/11/Cassirer_Ernst_An_essay_ on_man_An_introduction_1944.pdf (14 October 2015)

Eliot, T. S. Tradition and Individual Talent. http://seas3.elte.hu/coursematerial/ RuttkayVeronika/tradition_and_individual_talent.pdf (14 October 2015)

Emerson, Ralph Waldo. The Poet. http://www.emersoncentral.com/poet.htm (14 October 2015)

Filreis, Alan. 1992. Beyond the Rhetorician's Touch: Stevens' Painterly Abstractions. American Literary History vol. 2 (Spring): 230-263.

---. 1994. Modernism from Right to Left. Cambridge: Cambridge University Press.

Frost, Robert. The Road Not Taken. http://www.bartleby.com/119/1.html (14 October 2015)

Heidegger, Martin. 1989. Lét és idô. [Being and Time.] Budapest: Gondolat.

Leonard, J. S. and C. E. Wharton. 1988. The Fluent Mundo. Wallace Stevens and the Structure of Reality. Athens and London: University of Georgia Press.

Longenbach, James. 1991. Wallace Stevens. The Plain Sense of Things. New York and Oxford: Oxford University Press.

Nietzsche, Friedrich. Thus Spoke Zarathustra. http://4umi.com/nietzsche/ zarathustra/1 (14 October 2015)

Palmer, Jedediah. 1992. Stevens' The Poems of Our Climate. Florida: Florida Atlantic University Press.

Pfau, Thomas. 1999. Confluences: Reading Wallace Stevens. Southwestern Review vol. 84 no. 4: 60-115.

Stevens, Wallace. 1972. The Palm at the End of the Mind. Selected Poems and a Play. New York: Vintage.

---. Adagia. https://arspythia.wordpress.com/2013/04/05/wallace-stevens-fromadagia-part-one/ (14 October 2015)

Walzer, Kevin. 2000. Wallace Stevens, Meter and Natural Classicism. Critic vol. 62 no. 2: 45-53. 